\title{
ILK wt Allele
}

National Cancer Institute

\section{Source}

National Cancer Institute. ILK wt Allele. NCI Thesaurus. Code C52806.

Human ILK wild-type allele is located within 11p15.5-p15.4 and is approximately $7 \mathrm{~kb}$ in length. This allele, which encodes integrin-linked protein kinase, plays a role in the progression of integrin-mediated signaling. 